\title{
A CHEGADA DA TECNOLOGIA NA EDUCAÇÃO DO POVO XERENTE
}

\author{
BRITO $^{1}$, Wakedi da Mata \\ Pesquisadora da Ação 'Saberes Indígenas na Escola'
}

\section{RESUMO}

Este artigo é sobre a chegada da tecnologia no meio do nosso cotidiano, que mudou totalmente o hábito da convivência na educação Akwẽ.

Palavras-chave: Xerente. Tecnologias. Mudanças.

\section{ABSTRACT}

This article is about the arrival of technology in the midst of our everyday life that totally changed the habit of coexistence in Akwẽ education.

Key words: Xerente. Technologies. Changes.

Nos anos 50, os povos indígenas Xerente se comunicavam com a fumaça de fogo, pois eles tocavam fogo para as pessoas saberem que alguém estava vindo para contar algo novo, de bom ou ruim. Assim se comunicavam. Comunicavam-se com a fumaça de fogo, quando alguém vinha de longe para dar notícia, visitar, ou até num conflito. Eles iam para a caçada se comunicando assim também. Assim, se anunciava a chegada de pessoas ou servia de aviso de pessoas estranhas.

O surgimento das tecnologias fez mudanças mais rápidas nos mais jovens das aldeias. Também está acontecendo em outras etnias, com os outros parentes indígenas.

Acho que foi a partir dos anos 90 ou 2000 que começaram a chegar as primeiras manifestações de tecnologias. Foi grande projeto proposto pelo governador José Wilson Siqueira Campos, implantado na Terra Indígena Xerente, denominada PIN Xerente. As tecnologias invadiram o cotidiano do povo Akwẽ, como música em CD's, enfim, os aparelhos de todos os tipos, até nos dias atuais. Muitas das vezes o som alto atrapalha os vizinhos mais próximos de suas casas.

1 Rede UFG/UFT/UFMA. Professora de Educação Básica. 
Quanto mais os Akwẽ estão mais próximos com os brancos, ktawano, mais facilita a utilizar as novas tecnologias. Falar da educação escolar indígena é muito importante, porque muitas das tecnologias hoje fazem parte do relacionamento e aos conhecimentos.

Os indígenas começaram a usar o rádio mais ou menos a partir de 1970 para se comunicarem entre aldeias, sobre preservação de seu território. Servia para mandar notícia, como invasão de territórios, queimadas e notícia com os outros parentes.

Essa ferramenta veio trazida nas aldeias pelo SPI - Serviço de Proteção ao Índio. Tinha só cinco postos indígenas com rádio de comunicação. Precisava de combustível para funcionar. Quem se responsabilizava era chefe da FUNAI, não indígena ou indígena. A comunicação, dizem que era feita na língua materna para os demais conhecerem melhor a notícia repassada.

Energia elétrica chegou às aldeias na década de 90 . Só a rede, sem ser instalação nas casas nem nas comunidades, porque a maioria das pessoas não tinha condição financeira para instalar energia.

A energia trouxe para a comunidade muitas possibilidades de uso, como geladeira, sons, TVs e também nos serviu de ter iluminação dando oportunidade de ter aula à noite. A internet na comunicação foi necessária para os professores e nos postos de saúde para atendimentos nas suas comunidades locais.

O celular e a internet estão relacionados com a educação e a saúde, uma saída que facilitou o aprendizado nas Universidades também. Os mais novos agora estão se comunicando através de celulares digitais, Facebook, WhatsApp e e-mails. Até os mais velhos também estão inseridos. Estamos vivenciando junto com a sociedade envolvente. 